\title{
Nutritional characteristics of biofortified common beans
}

\author{
Priscila BRIGIDE ${ }^{1 *}$, Solange Guidolin CANNIATTI-BRAZACA ${ }^{1}$, Maira Oliveira SILVA ${ }^{1}$
}

\begin{abstract}
Iron and zinc deficiency can cause anemia and alterations in the immune response and impair work capacity. To minimize this problem, biofortification has been developed to improve and/or maintain the nutritional status of the population. Beans are an important source of carbohydrates, proteins, and minerals. The objective of this study is to characterize biofortified beans, quantify the minerals in different cultivars, and determine mineral dialysis. Grains of raw and cooked beans were analyzed for moisture, protein, lipids, fiber, minerals, and in vitro availability using four treatments and one control. The data were analyzed using ANOVA, and the Tukey test $(\mathrm{p} \leq 0.05)$. The chemical composition of the raw and cooked treatments showed a moisture content ranging from 13.4 to $81.4 \%$, protein from 22.24 to $31.59 \%$, lipids from 1.66 to $2.22 \%$, fiber from 16.81 to $40.63 \%$, carbohydrates from 27.80 to $34.78 \%$, and ash from 4.1 to $4.82 \%$. Different varieties of beans showed statistically significant differences in iron and zinc content compared to the control cultivar (Pérola). The iron content differed significantly from that of the Pérola cultivar in the raw treatment, while in the cooked treatment, the control cultivar did not differ from the Piratã. The same behavior was observed for the zinc content in both treatments. There was no significant difference between the cultivars in the treatments in terms of the content of the dialysis of Calcium (Ca), Iron (Fe), Magnesium (Mg), and Zinc (Zn).
\end{abstract}

Keywords: beans; biofortification; iron; minerals; availability; nutrition.

\section{Introduction}

Vitamin and mineral deficiencies can interfere with all aspects of human development; these conditions have physical and socioeconomic consequences that can affect the progress of an entire country. Beans and meat are both important sources of iron, and approximately $1-7 \%$ of this mineral in dietary sources are absorbed consumed alone. Beans have great social and economic importance in Brazil because they are one of the main sources of protein, plant-derived micronutrients, and minerals. However, the health benefits of beans are associated with their processing methods. Beans should be cooked or processed before intake. The processing of legumes not only improves their flavor and palatability, but it also increases the bioavailability of nutrients and reduces flatulence factors (raffinose oligosaccharides) (Cardador-Martinez et al., 2002; Xu et al., 2009).

Cooking legumes improves their nutritional value by reducing antinutrients, such as phytic acid and tannins, and improving protein and starch digestibility. Moreover, cooking imparts desirable sensory properties to grains (Ranilla et al., 2009). This study aims to determine the chemical composition and $\mathrm{Ca}, \mathrm{Fe}, \mathrm{Mg}$ and $\mathrm{Zn}$ avalilability in biofortified raw and cooked bean cultivars compared with a non-biofortified control.

\section{Materials and methods}

\subsection{Bean cultivars and bean flour production}

The common biofortified bean varieties (P. vulgaris L.) Supremo, Porto Real, Piratã, Brazil and Perola (control) were donated by EMBRAPA - Rice and Beans Research Center
(EMBRAPA - Centro de Pesquisa Arroz e Feijão) in August 2010. The beans were analyzed raw and thermally processed. For the analysis of the raw grains, the samples were ground using a knife mill and passed through a 30-mesh sieve to obtain the flour consistency. The flour was stored in closed polyethylene bags, stored at $4{ }^{\circ} \mathrm{C}$, and then analyzed. For the analysis of the cooked beans, the grains were soaked for 10 hours in distilled water (1:3); the water was then discarded and the grains were mixed with water $(1: 3)$ and cooked in an autoclave at $121^{\circ} \mathrm{C}$ for 10 minutes. After cooking, the samples were lyophilized, placed in plastic bags, and subsequently ground and kept refrigerated until analysis.

\subsection{Determination of chemical composition}

Humidity was determined in an oven set at $105^{\circ} \mathrm{C}$, according to standard procedures detailed by AOAC (Association of Official Analytical Chemists, 2005).

The ash content was determined by calcination in a furnace at $550{ }^{\circ} \mathrm{C}$ using the method described by AOAC (Association of Official Analytical Chemists, 2005).

The total nitrogen content was quantified by the Kjeldahl method, as described by AOAC (Association of Official Analytical Chemists, 2005), and the protein content was calculated by multiplying the result by 6.25 .

The lipid content was determined by Soxhlet extraction according to the method described by AOAC (Association of Official Analytical Chemists, 2005), using petroleum ether as the extractor. 
The carbohydrate content was determined by subtracting the sum of the lipid, protein, moisture and ash contents from 100 (Association of Official Analytical Chemists, 2005).

\section{Determination of dietary fiber}

The determination of total dietary fiber (TDF) and insoluble (IDF) and soluble dietary fiber (SDF) of the bean samples was performed according to the gravimetric enzymatic method using \pm heat-resistant amylase, pepsin, and pancreatin for enzymatic hydrolysis. Filtration was performed using glass crucibles with sintered glass plates and diatomaceous earth filter aid. Total fiber was determined as the sum of IDF and SDF (Asp et al., 1983).

\section{Determination of mineral content}

The content of mineral elements was determined using digestion with nitric-perchloric acid. After cooling and diluting the material with deionized water, the samples were analyzed using an atomic absorption spectrophotometer at the Laboratory of Plant Mineral Nutrition, Department of Soils and Plant Nutrition, ESALQ. The following wavelengths were used: $422.7 \mathrm{~nm}$ for calcium, $248.3 \mathrm{~nm}$ for iron, $285.2 \mathrm{~nm}$ for magnesium, and $213.9 \mathrm{~nm}$ for zinc (Association of Official Analytical Chemists, 2005; Sarruge \& Haag, 1974).

\section{Mineral dialysis}

The analysis of mineral dialysis was performed according to the method proposed by Whittaker et al. (1989), in which $5 \mathrm{~g}$ of the sample were homogenized with $17 \mathrm{~mL}$ of deionized water. Next, $6 \mathrm{~N} \mathrm{HCl}$ was added until the $\mathrm{pH}$ reached 2; then, $0.01 \mathrm{~N} \mathrm{HCl}$ was added to a final volume of $34 \mathrm{~mL}$. Digestion was performed by adding $1.07 \mathrm{~mL}$ of $\mathrm{HCl}$-pepsin and incubating at $37^{\circ} \mathrm{C}$ in a shaking water bath at $200 \mathrm{rpm}$ for 2 hours. Finally, 7 $\mathrm{g}$ of the digested sample were weighed, to measure the acidity, and $1.7 \mathrm{~mL}$ of pancreatin-bile was added and titrated with $0.5 \mathrm{~N}$ $\mathrm{KOH}$ until a $\mathrm{pH}$ of 7.5 was reached. According to the volume of $\mathrm{KOH}$ titrated, the same volume of $0.5 \mathrm{~N} \mathrm{NaHCO}_{3}$ was diluted in $8.5 \mathrm{~mL}$ of distilled water. Dialysis was performed by placing the digested material in dialysis bags. Three times the volume of 0.5 $\mathrm{N} \mathrm{NaHCO}_{3}$ were used so that the digested sample would remain submerged. The vials were covered and agitated for $30 \mathrm{~min}$ at $37^{\circ} \mathrm{C}$. A pancreatin-bile suspension was added and incubated for 2 hours. Deionized water was added to the dialyzed content to a final volume of $10 \mathrm{~mL}$. The determination of minerals was performed by atomic absorption spectrophotometry.

\section{Statistical analysis}

A completely randomized design with three replicates and each one with three samples was used. Variance analysis (the F-test) was carried out, and the means of the different treatments were compared using the Tukey test $(\mathrm{p}<0.05)(\mathrm{SAS})$.

\section{Results and discussion}

Beans provide significant amounts of protein and dietary fiber and are an excellent source of some minerals (Brigide, 2002; $\mathrm{Hu}$ et al., 2006; Aparicio-Fernandez et al., 2005; Villavicencio et al., 2000), as shown in Table 1. In order to improve the nutritional quality of beans, methods such as maceration are used (Barampama \& Simard, 1994, 1995); these methods are similar to the cooking methods commonly used by people for preparing beans. The efficacy of these methods varies depending on the cultivar and treatment. All of these processes reduce antinutritional factors (Barampama \& Simard, 1994), but other phenomena may also occur, such as losses of the macro- and micronutrients, particularly vitamins and minerals, during the processes of maceration and cooking (Barampama \& Simard, 1995; Rehman et al., 2001).

Maceration and cooking processes resulted in greater levels of moisture and carbohydrates than those in the raw beans (Table 1). The average moisture content was 13.89 to $15.62 \%$ in raw beans and 76.96 to $81.40 \%$ in macerated/cooked beans. The process of maceration/cooking favored hydration of the grains, which explains their high moisture content. These values are close to those found by Oliveira et al. (2008) and RamírezCárdenasi et al. (2008), who found 9 to $11 \%$ on a dry basis in raw beans. The values found in the cooked beans are similar to those reported by Brigide \& Canniatti-Brazaca (2006). The Porto Real and Brasil cultivars had the highest values in the raw treatment, while the Supremo cultivar exhibited the highest value in the maceration/cooked treatment.

According to Esteves (2000), the protein content of beans on a dry basis is between 22 and $26 \%$, values similar to the range of 23.38 to $31.59 \%$, found in the raw treatment, and 22.24 to $33.10 \%$ found in the macerated/cooked treatment (Table 1). In a study on beans prepared in a pressure cooker, Oliveira et al. (2001a) reported protein values of $19.8 \%$ in beans cooked without maceration and $19.2 \%$ and $19.3 \%$ in macerated and cooked beans with and without the maceration water, respectively; thus, replacing the maceration water did not affect these values (Oliveira et al., 2001b) and the values were lower than those found in the present study in cooked beans, which ranged from 20.54 to $34.04 \%$ (Table 1). Among the cultivars evaluated, Brasil and Supremo cultivars showed the highest levels of protein in the raw treatment, while the Supremo cultivar showed a higher protein content in the macerated/cooked treatment. Protein provided by beans is an important nutrient to meet the nutritional requirements of the Brazilian population

Compared to the content of other macronutrients, lipid content is generally low in the common beans.

The fat content of raw beans ranged from 1.66 to $2.13 \%$ and from 1.77 to $2.22 \%$ in cooked beans in the cultivars studied (Table 1). Barampama \& Simard (1993) found similar values (from 1.9 to $2.0 \%$ ) to the data presented in the present study. The differences in the ether extract content may be explained by the different cultivars used and cultivation area and practices. The lipid content did not vary with the maceration/cooking methods used, i.e., they did not affect the content of this nutrient. However, Porto Real, Pérola, and Brasil cultivars had the highest lipid contents in the raw treatment, while Pérola and Supremo cultivars had the highest levels in the macerated/ cooked treatment. Beans are not a source of lipids. 


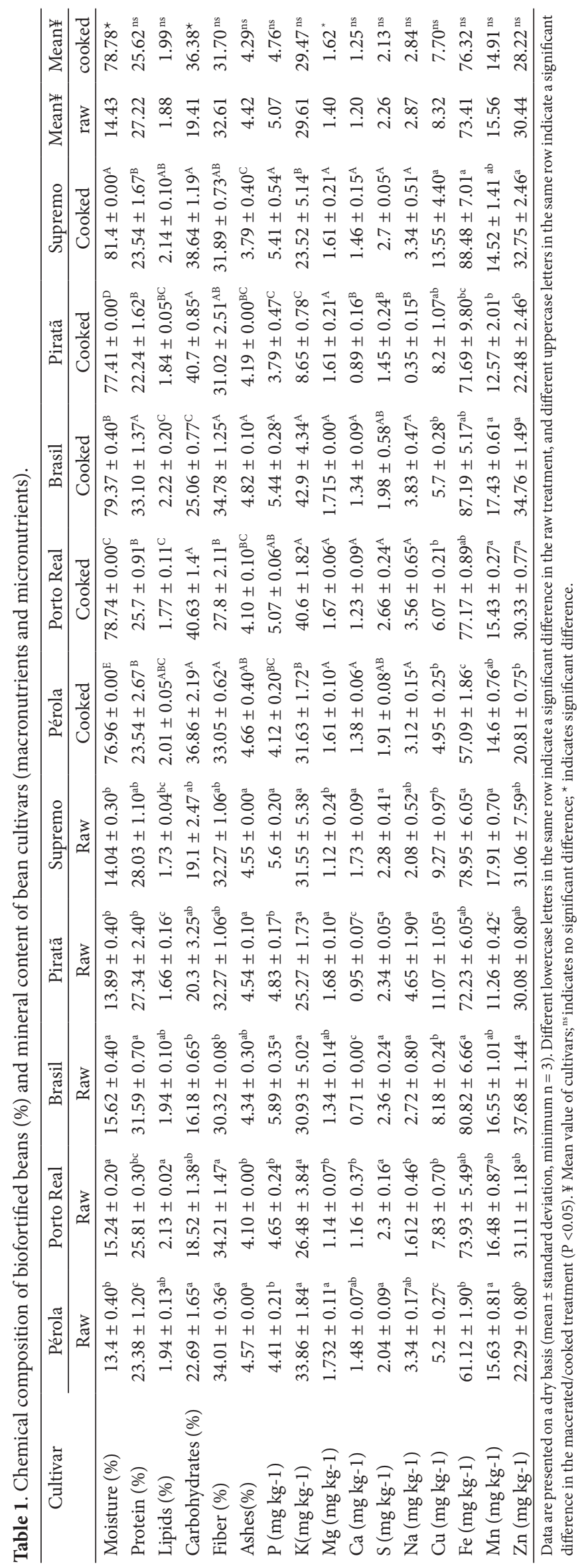


The amounts of available carbohydrates in the samples, which were obtained by difference, ranged from 16.18 to $22.68 \%$ in raw beans and 25.07 to $40.63 \%$ in cooked beans. All of the cultivars, except for Brasil cultivar, had the same carbohydrate content regardless of treatment. Carbohydrates and proteins are major components of dry beans. The carbohydrate content of the cultivars in raw and cooked forms is in agreement with those reported by other authors (Brigide \& Canniatti-Brazaca, 2006; Sathe, 2002). The cooking process causes significant differences in carbohydrate content, and beans provides the diet with large amounts of carbohydrates.

The total dietary fiber ranged from 30.32 to $34.01 \%$ in raw beans and from 27.80 to $31.78 \%$ in cooked beans. The difference between these treatments was not statistically significant. Brasil cultivar had lower total dietary fiber value in the raw treatment, but it did not differ from the Piratã and Supremo cultivars. The macerated/cooked treatment of Porto Real cultivar was different from the cooked treatment of Pérola and Brasil cultivars, showing a lower fiber content. Acevedo \& Bressani (1990) found a $26.77 \%$ dietary fiber content in black beans and $24.65 \%$ in white beans. Londero et al. (2008) found different values of dietary fiber in cultivars grown in different environments. Gonzáles (2000) noted that heat treatments can have variable effects on dietary fiber and that cooking causes disruption of the cellular components of beans (cellulose, hemicellulose, lignin, pectin and gums). The cooking process results in interactions between proteins and lipids, and it causes qualitative and quantitative changes in the composition of total dietary fiber of cooked foods compared to that of raw foods.

Dietary fiber present in beans increases fiber intake in the Brazilian population.

There was no significant difference between the ash content of the raw cultivars, which ranged from 4.1 to $4.57 \%$, and of the cooked beans, which ranged from 3.79 to $4.82 \%$.

There was no significant difference between Porto Real cultivar and the other cultivars in the raw treatment, except for the Brasil cultivar, while Pérola and Brasil cultivars had higher ash contents in the other treatments.

According to Barampama \& Simard (1993), the ash content of beans varies from 3.8 to $4.5 \%$; these values are similar to those of the samples evaluated in the present study (Table 1). Lemessa (2004) found lower values in grains that were cooked after maceration, which is in agreement with the data presented in Table 1. Using maceration water to cook the beans preserved the ash content because maceration causes leaching of minerals. When the maceration water was not discarded, the solubilized minerals were maintained (Barampama \& Simard, 1995).

Costa et al. (2006) found an ash value of $4 \%$ in macerated beans and beans cooked in a pressure cooker in the same maceration water; this value is lower than those presented in Table 1. This difference may be due to variations in cultivation, plantation area, and the cultivar of the grains used.

The mineral contents of common bean cultivars are presented in Table 1. The consumption of beans increases the amount of several minerals in the diet. There was no significant difference between the raw and macerated/cooked treatments in the P content found in this study. In the literature, the P

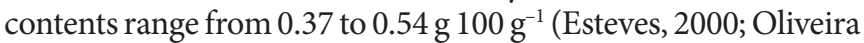
et al., 2001b). Bean lines with higher levels than the literature values were found in the present study, for instance, the levels in the Supremo and Brasil cultivars were higher in the raw and cooked treatments. Their levels were also higher than those of the Porto Real cultivar.

The range of $\mathrm{K}$ found in raw beans in the current study varied from 25.27 (Piratã) to 33.86 (Pérola) $\mathrm{mg} \mathrm{kg}^{-1}$, and in the cooked treatment it ranged from 23.52 (Supremo) to 42.9 (Brasil) $\mathrm{mg} \mathrm{kg}^{-1}$. There were no differences between the levels found in the raw cultivars, but the Porto Real and Brasil cultivars showed higher values in the macerated/cooked treatment. There was no significant difference between the raw and macerated/ cooked treatments.

The Ca content ranged from 0.71 (Brasil) to $1.73 \mathrm{mg} \mathrm{kg}^{-1}$ (Supremo) and 0.89 (Piratã) to $1.46 \mathrm{mg} \mathrm{kg}^{-1}$ (Supremo). Several authors found Ca levels in $100 \mathrm{~g}$ ranging from $0.06 \mathrm{~g}$ to $0.28 \mathrm{~g}$ (Esteves, 2000; Oliveira et al., 2001b).The Ca levels did not differ between the raw and macerated/cooked treatments.

The magnesium content had a significant difference between the raw and macerated/cooked beans. The Mg content ranged from 1.12 to $1.73 \mathrm{mg} \mathrm{kg}^{-1}$ in the raw treatment and from 1.61 to $1.71 \mathrm{mg} \mathrm{kg}^{-1}$ in the macerated/cooked treatment. The Pérola, Brasil, and Piratã cultivars had the highest levels of $\mathrm{Mg}$ in the raw treatment, while there were no differences between the cultivars in the macerated/cooked treatment. The average magnesium content in various North American beans (United States Departament of Agriculture, 2013) were similar to those found by Taco (Universidade Estadual de Campinas, 2011), with variations ranging from $140 \mathrm{mg} 100 \mathrm{~g}^{-1}$ (kidney bean) to

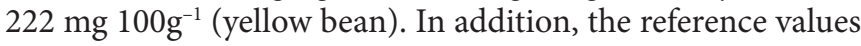
were higher than the average levels of magnesium found in the five varieties studied.

The sulfur content varied from 2.04 to $2.36 \mathrm{mg} \mathrm{kg}^{-1}$ in the raw treatment, and in the macerated/cooked treatments it varied from 1.45 to $2.66 \mathrm{mg} \mathrm{kg}^{-}$. There was no significant difference between the raw and the macerated/cooked treatments. The Porto Real cultivar showed the lowest sodium content, differing significantly from the Piratã and Supremo cultivars in the raw treatment, with contents ranging from 1.61 to $4.65 \mathrm{mg} \mathrm{kg}^{-1}$ and from 0.35 to $3.83 \mathrm{mg} \mathrm{kg}^{-1}$ in the macerated/cooked treatment. There was no difference between the raw and cooked treatments. Cooked Piratã had the lowest value between the cultivars,

The Cu levels ranged from 5.2 to $11.0773 \mathrm{mg} \mathrm{kg}^{-1}$ and 4.96 to $13.3373 \mathrm{mg} \mathrm{kg}^{-1}$ in the raw and macerated/cooked treatments, respectively; there was no difference between the raw and the cooked treatments. Raw Piratã cultivar had the highest CU value, which was not different from that of the cooked Supremo cultivar. Studies in the literature show $\mathrm{Cu}$ values ranging from 1.4 to $9.073 \mathrm{~g} \mathrm{~kg}^{-1}$ (Esteves, 2000; Oliveira et al., 2001b) in different lines of beans. The Cu levels found in the present study are higher than the values reported in the literature.

In the raw treatment, the lines showed Fe levels between 61.12 (Pérola) and $80.82 \mathrm{mg} \mathrm{kg}^{-1}$ (Supremo), differing from that 
of the Pérola cultivar (control) cultivar; similar to the what was found in the macerated/cooked treatment, in which the iron content varied from 57.09 (Pérola) to $88.48 \mathrm{mg} \mathrm{kg}^{-1}$ (Supremo). The Pérola (control) cultivar showed the lowest amount of Fe. The standard reference values provided by the USDA (United States Departament of Agriculture, 2013) for the average content of Fe are very similar, varying from 5 to $8 \mathrm{mg}^{100 \mathrm{~g}^{-1}}$.

The manganese content varied from 11.26 to 17.91 $73 \mathrm{mg} \mathrm{kg}^{-1}$ in the raw treatment and from 12.57 to $17.4373 \mathrm{mg}$ $\mathrm{kg}^{-1}$ in the macerated/cooked treatment; there was no significant difference between the raw and cooked treatments. However, the Piratã cultivar had the lowest value in the raw and cooked cultivar treatments, and showed no difference from the Supremo and Pérola cultivars (Table 1).

The zinc content ranged from 22.29 (Pérola) to $37.68 \mathrm{mg} \mathrm{kg}^{-1}$ (Brasil), with a significant difference from the raw cultivar. The macerated/cooked cultivars ranged from 20.81 (Pérola) to 34.76 (Brasil) $\mathrm{mg} \mathrm{kg}^{-1}$. Piratã and Pérola cultivar differ from the other (a)
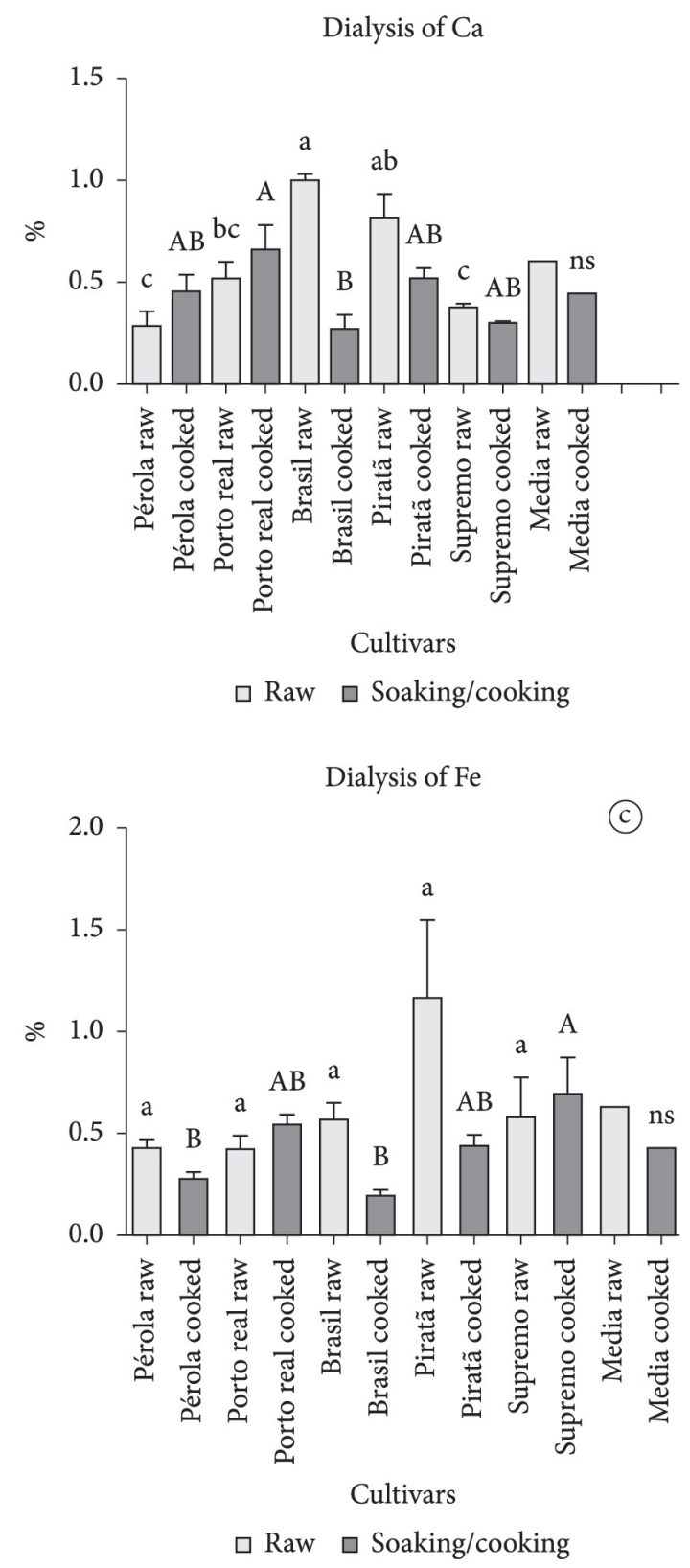
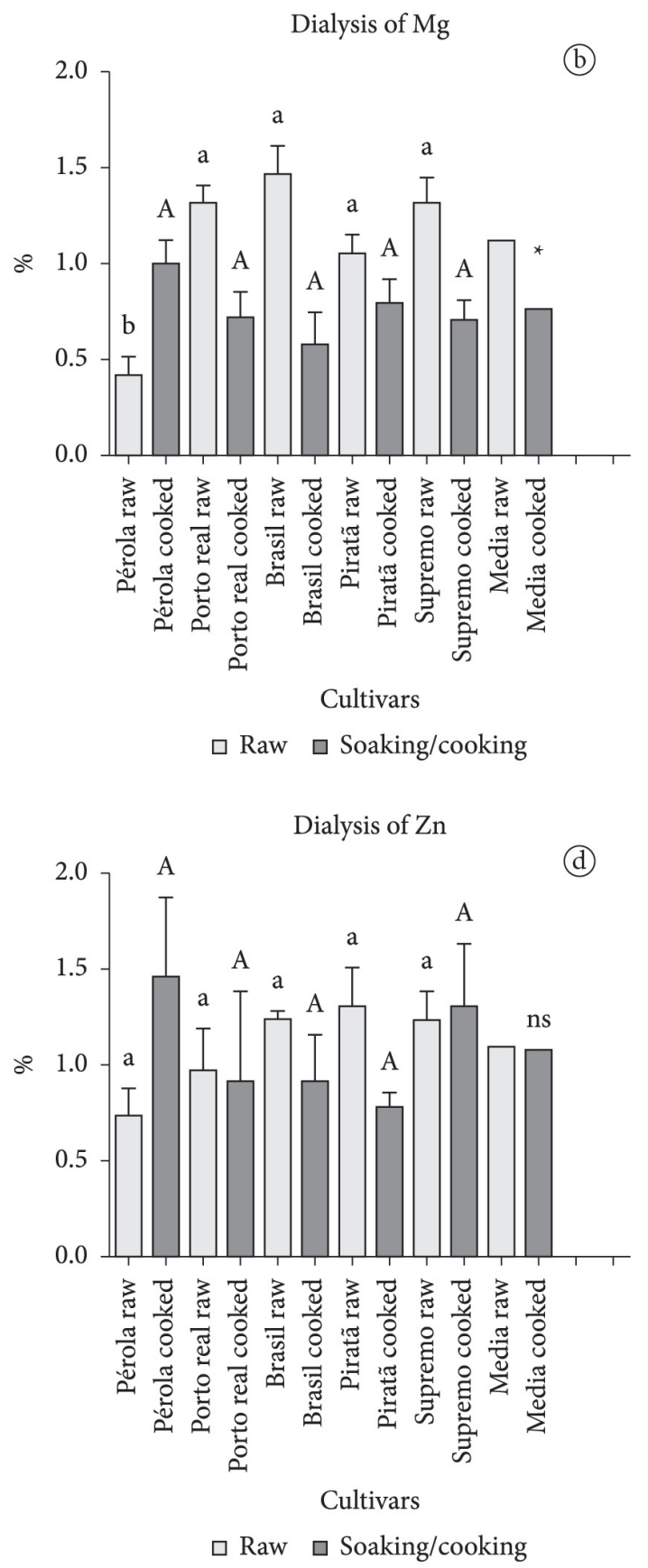

Figure 1. Dialysis (\%) of the minerals $\mathrm{Ca}(1 \mathrm{a}), \mathrm{Mg}(\mathrm{lb}), \mathrm{Fe}(1 \mathrm{c})$, and $\mathrm{Zn}(1 \mathrm{~d})$. Data are presented on a dry basis (means \pm standard deviation, minimum $n=3$ ). Different lowercase letters in the same column indicate a significant difference in the raw treatment, and different uppercase letters in the same column indicate a significant difference in the macerated/cooked treatment $(\mathrm{P}<0.05)$. Different uppercase letters in the same row indicate statistically significant differences $(\mathrm{P}<0.05)$ Mean value of cultivars; ${ }^{\text {ns }}$ indicates no significant difference; ${ }^{*}$ indicates significant difference. 
cultivars. There was no significant difference between the raw and cooked treatments. The biofortified varieties differed from the control, with the exception of the macerated/cooked Pérola cultivar. According to some studies, the $\mathrm{Zn}$ levels found in various beans ranged from 20.20 to $36 \mathrm{mg} \mathrm{kg}^{-1}$ (Esteves, 2000; Oliveira et al., 2001b), which is close to the results found in this study.

There were no statistically significant differences between the cultivars in terms of the minerals analyzed. Since all varieties were grown under strictly controlled conditions of soil, water and agricultural practices, these results can be considered highly representative of the characteristics of beans and the advantages of each variety in terms of nutrient composition.

Beans are a good source of minerals, such as $\mathrm{Ca}, \mathrm{Mg}, \mathrm{Fe}$, and $\mathrm{Zn}$, as shown in Table 1; however, according to Erdman Jr. (1981), their bioavailability depends on factors endogenous and exogenous to the grain. The endogenous factors are related to the biochemical composition of the grain, such as phytic acid, fiber, amino acids, and proteins that can chelate minerals quite easily. Moreover, the interaction of these compounds during food processing, preparation, or in the body may change their bioavailability, as shown in Figure 1.

With regard to the in vitro availability of minerals, Brasil and Piratã cultivars showed the highest values of Ca dialysis in the raw treatment, but Brasil cultivar showed the lowest content of Ca dialysis in the macerated/cooked treatment. The treatments showed no significant difference, demonstrating that the macerating/cooking treatment does not affect the levels of dialysis.

Pérola cultivar was the only one that differed from the others in terms of $\mathrm{Mg}$ dialysis; lowest value was found in the raw treatment. The macerated/cooked treatment showed no differences between the cultivars. However, there was a significant difference between the raw and macerated/cooked treatments.

The raw-treatment cultivars did not differ in terms of $\mathrm{Fe}$ dialysis, but the macerated/cooked Porto Real, Piratã, and Supremo cultivars showed the highest Fe dialysis values. There was no significant difference between the raw and macerated/ cooked treatments.

The cultivars did not differ in terms of zinc dialysis, regardless of the treatment, and there was no significant difference between the treatments.

Sebastia et al. (2001) found similar values to those presented in this study, with Ca dialysis of $0.15 \mathrm{mg} / \mathrm{g}$ in the raw treatment and $0.13 \mathrm{mg} / \mathrm{g}$ in the cooked treatment. Zinc had the same dialysis content, $0.32 \mu \mathrm{g} / \mathrm{g}$, regardless of the treatment, and iron had values of $0.045 \mu \mathrm{g} / \mathrm{g}$ in the raw treatment and $0.017 \mu \mathrm{g} / \mathrm{g}$ in the cooked treatment.

Pinn (1992) found a dialysis value of $0.82 \%$ of iron in beans, which is close to the results presented in this study. Other authors found higher values for the Fe dialysis; Martínez et al. (1998), reported that the average values of in vitro availability of iron in cooked beans in the Cleo, Strike, and Sentry varieties of Phaseolus vulgaris were 4.1, 5.9 and 9\%.
Amaya et al. (1991) found the following variations in the total iron during the processing of black beans (Phaseolus vulgaris): $2.9-3.8 \mathrm{mg} / 100 \mathrm{~g}$ of beans without broth, 4.1-5.8 $\mathrm{mg} / 100 \mathrm{~g}$ of beans with broth, and 12.6-15.5 mg/100 $\mathrm{g}$ of broth. Ionizable iron, indicative of iron bioavailability, ranged from 0.31 to $0.41 \mathrm{mg}$ in beans without broth and 0.29 to $0.41 \mathrm{mg}$ in beans with broth. Although these values are similar, the values found in the bean broth ranged from 1.13 to $1.92 \mathrm{mg}$.

Pastor-Cavada et al. (2013) evaluated whole corn and rice with legumes in extrused produts and found mineral availability of iron ranging from 6.4 to $16.3 \%$ and 10 to $16.3 \%$ for zinc. Hemalatha et al. (2007) found a bioavailability of zinc value of $52.5 \%$ and $10.2 \%$ for Fe in French beans; these values are higher than those found in the current study. Sandberg (2002) stated that the presence of phytic acid, polyphenols, and dietary fiber in these food sources exert antagonistic effects on the absorption of calcium, iron, and zinc, which could explain the low availability of those minerals. The nutritional composition of beans can vary widely due to varietal differences and environmental conditions of production, but the grains of the aforementioned cultivars were subjected to the same plantation conditions, which guarantee equal treatment in cultivation. Variations in the micronutrient content of grains can be attributed to a number of factors: plant characteristics, such as plant age, maturity, species, variety, cultivar, and diet; environmental features, such as climate, soil, rainfall, and season; and processing factors, such as storage time, temperature, method of preservation, and preparation of food. Therefore, it can be said that the grains analyzed in this study had similar characteristics.

\section{Conclusion}

Under the experimental conditions used, the chemical composition values indicated that the levels of moisture, protein, ether extract, ash, fiber, and carbohydrate differed between the studied cultivars. In contrast, moisture and fiber content differed between the raw and cooked treatments, with the presence of increased moisture and carbohydrates in the cooked beans.

In terms of the mineral content of the cultivars assessed, when compared to the control, the iron content of Pérola cultivar was the highest in the biofortified beans. However, in the macerated/cooked treatment, the iron content of the biofortified beans did not differ from that of the Piratã cultivar. The same behavior was observed in terms of zinc content in both treatments. All varieties studied belong to the same species, Phaseolus vulgaris, and all cultivars were treated under the same cultivation, harvesting, and storage conditions and exhibited significant amounts of $\mathrm{K}, \mathrm{Ca}, \mathrm{Fe}, \mathrm{Mg}, \mathrm{Mn}$, and $\mathrm{Zn}$. However, all the cultivars had an exceptionally large concentration of nutrients.

The dialysis content of $\mathrm{Ca}, \mathrm{Fe}$, and $\mathrm{Zn}$ did not differ between treatments, demonstrating that the treatments did not influence the availability of these minerals. The cooked treatment showed a lower availability of $\mathrm{Mg}$. In comparison to the control cultivar (Pérola), the content of Fe dialysis were higher in the biofortified beans between the studied cultivars, while in the macerated/ cooked treatment, the Pérola cultivar did not differ from Brasil 
cultivar. The $\mathrm{Zn}$ content of the control cultivar did not differ from the other cultivars in both treatments.

\section{Acknowledgments}

The authors gratefully acknowledge EMBRAPA - Arroz e Feijão/Brasil. This research was supported by FAPESP 2009/14294-4.

\section{References}

Acevedo, E., \& Bressani R. (1990). Contenido de fibra dietetica y digestibilidad del nitrogeno en alimentos centroamericanos. Archivos Latinoamericanos de Nutricion, 40(3), 439-451. PMid:1966870.

Amaya, H., Acevedo, E., \& Bressani, R. (1991). Efecto del recalentamiento sobre la disponibilidad de hierro y el valor nutritivo de la proteina del frijol negro (Phaseolus vulgaris) cocido. Archivos Latinoamericanos de Nutricion, 41(2), 222-237. PMid:1811452.

Aparicio-Fernandez, X., Yousef, G. G., Loarca-Pina, G., Mejia, E., \& Lila, M. A. (2005). Characterization of polyphenolics in the seed of black Jamapa bean (Phaseolus vulgaris L.). Journal of Agricultural and Food Chemistry, 53(11), 4615-4622. PMid:15913334. http:// dx.doi.org/10.1021/jf047802o

Asp, N. G., Claes, G. J., Hallmer, H., \& Siljestron, M. (1983). Rapid enzymatic assay of insoluble and soluble dietary fiber. Journal of Agricultural and Food Chemistry, 31(3), 476-482. PMid:6309935. http://dx.doi.org/10.1021/jf00117a003

Association of Official Analytical Chemists - AOAC. (2005). Official methods of analysis of the Association Analytical Chemists (18th ed.). Maryland: AOAC.

Barampama, Z., \& Simard, R. E. (1993). Nutrient composition, protein quality and antinutritional factors of some varieties of dry beans (Phaseolus vulgaris) grown in Burundi. Food Chemistry, 47(2), 1567. http://dx.doi.org/10.1016/0308-8146(93)90238-B

Barampama, Z., \& Simard, R. E. (1994). Oligosaccharides, antinutritional factors and protein digestibility of dry beans as affected by processing. Journal of Food Science, 59(4), 833-838. http://dx.doi.org/10.1111/j.1365-2621.1994.tb08139.x

Barampama, Z., \& Simard, R. E. (1995). Effects of soaking, cooking and fermentation on composition, in vitro starch digestibility and nutritive value of common beans. Plant Foods for Human Nutrition, 48(4), 349-365. PMid:8882373. http://dx.doi.org/10.1007/ BF01088494

Brigide, P. (2002). Disponibilidade de ferro em grãos de feijão comum (Phaseolus vulgaris L.) irradiados (Dissertação de mestrado). Escola Superior de Agricultura "Luiz de Queiroz", Universidade de São Paulo, Piracicaba, São Paulo.

Brigide, P., \& Canniatti-Brazaca, S. G. (2006). Antinutrients and in vitro availability of iron in irradiated common beans (Phaseolus vulgaris). Food Chemistry, 98(1), 85-89. http://dx.doi.org/10.1016/j. foodchem.2005.05.054

Cardador-Martinez, A., Loarca-Pina, G. L., \& Oomah, B. D. (2002). Antioxidant activity in common beans (Phaseolus vulgaris L.). Journal of Agricultural and Food Chemistry, 50(24), 6975-6980. PMid:12428946. http://dx.doi.org/10.1021/jf020296n

Costa, G. E. A., Queiroz-Monici, K. S., Reis, S. M. P. M., \& Oliveira, A. C. (2006). Chemical composition, dietary fibre and resistant starch contents of raw and cooked peã, common bean, chickpea and lentil legumes. Food Chemistry, 94(3), 327-330. http://dx.doi. org/10.1016/j.foodchem.2004.11.020
Erdman Jr., J. W. (1981). Bioavailability of trace minerals from cereals and legumes. Cereal Chemistry, 58(1), 21-26.

Esteves, A. M. (2000). Comparação química e enzimática de seis linhagens de feijão (Phaseolus vulgaris L.) (Dissertação de mestrado). Universidade Federal de Lavras, Lavras, Minas Gerais.

Gonzáles, G. C. A. (2000). Efecto del tratamiento térmico sobre el contenido de fibra dietética total, soluble y insoluble en algunas leguminosas. Archivos Latinoamericanos de Nutricion, 50(3), 281285.

Hemalatha, S., Platel, K., \& Srinivasan, K. (2007). Zinc and iron contents and their bioaccessibility in cereals and pulses consumed in India. Food Chemistry, 102(4), 1328-1336. http://dx.doi.org/10.1016/j. foodchem.2006.07.015

Hu, Y., Cheng, Z, Heller, L. I., \& Glahn, R. (2006). Kaempferol in red and pinto bean seed (Phaseolus vulgaris L.) coats inhibits iron bioavailability using an in vitro digestion/human Caco-2 cell model. Journal of Agricultural and Food Chemistry, 54(24), 9254-9261. PMid:17117818. http://dx.doi.org/10.1021/jf0612981

Lemessa, F. (2004). Effects of traditional processing of haricot bean (Phaseolus vulgaris L.) on nutritional composition. Journal of Food Science and Technology, 41(1), 99-102.

Londero, P. M. G., Ribeiro, N. D., Poersch, N. L., Antunes, I. F., \& Nörnberg, J. L. (2008). Análise de frações de fibra alimentar em cultivares de feijão cultivadas em dois ambientes. Ciência Rural, 38(7), 2033-2036. http://dx.doi.org/10.1590/S010384782008000700037

Martínez, C., Ros, G., \& Periago, M. J., Ortuño, J., López, G., \& Rincón, F. (1998). In vitro protein digestibility and mineral avaibility of green beans (Phaseolus vulgaris L.) as influenced by variety and pod size. Journal of the Science of Food and Agriculture, 77(3), 414-420. http://dx.doi.org/10.1002/(SICI)1097-0010(199807)77:3<414::AIDJSFA60>3.0.CO;2-D

Oliveira, A. C., Carraro, F., Reis, S. M. P. M., Ramos, A. G., Helbig, E., Costa, E. L., Alvim, I. D., Queiroz, K. S., \& Luvielmo M. (2001a). A eliminação da água não absorvida durante a maceração do feijão comum aumentou o ganho de peso em ratos. Revista de Nutrição, 14(2), 153-155. http://dx.doi.org/10.1590/S141552732001000200009

Oliveira, A. C., Carraro, F., Reis, S. M. P. M., Ramos, A. G., Helbig, E., Costa, E. L., Alvim, I. D., Queiroz, K. S., \& Luvielmo, M. (2001b). O processamento doméstico do feijão-comum ocasionou uma redução nos fatores antinutricionais fitatos e taninos, no teor de amido e em fatores de flatulência rafinose, estaquiose e verbascose. Archivos Latinoamericanos de Nutricion, 51(3), 276-283. PMid:11795242.

Oliveira, V. R., Ribeiro, N. D., Jost, E., \& Londero, P. M. G. (2008). Nutritional and microbiological quality of common beans (Phaseolus vulgaris L.) cooked with or without the use of soaking water. Ciência e Agrotecnologia, 32(6), 1912-1918. http://dx.doi. org/10.1590/S1413-70542008000600034

Pastor-Cavada, E., Drago, S. R., González, R., Juan, R., Pastor, J. E., Alaiz, M., \& Vioque, J. (2013). Physical and nutritional properties of extrused products based on whole grain extruded products based on whole grain with the addition of wild legumes (Vicia lutea subsp. Lutea var. hirta and Vicia sativa subsp. sativa). International Journal of Food Sciences and Nutrition, 48, 1949-1955.

Pinn, A. B. R. O. (1992). Efeitos das radiações gama sobre a disponibilidade do ferro em feijões (Phaseolus vulgaris) (Dissertação de mestrado em Ciência de Alimentos). Faculdade de Ciências Farmacêuticas, Universidade de São Paulo, São Paulo.

Ramírez-Cárdenasi, L. R., Leonel, A. J., \& Costa, N. M. B. (2008). Efeito do processamento domésticosobre o teor de nutrientes e de fatores 
antinutricionais de diferentes cultivares de feijão comum. Ciênciae Tecnologia de Alimentos, 28(1), 200-213. http://dx.doi.org/10.1590/ S0101-20612008000100029

Ranilla, L. G., Genovese, M. I., \& Lajolo, F. M. (2009). Effect of different cooking conditions on phenolic compounds and antioxidant capacity of some selected brazilian bean (L.) cultivars. Journal of Agricultural and Food Chemistry, 57(13), 5734-5742. PMid:19507856. http://dx.doi.org/10.1021/jf900527v

Rehman, Z., Salariya, A. M., \& Zafar, S. I. (2001). Effect of processing on available carbohydrate content and starch digestibility of kidney beans (Phaseolus vulgaris L). Food Chemistry, 73(3), 351-355. http:// dx.doi.org/10.1016/S0308-8146(00)00311-3

Sandberg, A. S. (2002). Bioavailability of mineral in legumes. British Journal of Nutrition, 88(3), S281-285. PMid:12498628. http://dx.doi. org/10.1079/BJN/2002718

Sarruge, J. R., \& Haag, H. P. (1974). Análises químicas em plantas. Piracicaba: USP/ESALQ.

Sathe, S. K. (2002). Dry bean protein functionality. Critical Reviews in Biotechnology, 22(2), 175-223. PMid:12135167. http://dx.doi. org/10.1080/07388550290789487

Sebastia, V., Barbera, R., Farré, R., \& Lagarda, M. J. (2001). Effects of legume processing on calcium, iron and zinc contents and dialysabilities. Journal of Agricultural and Food Chemistry, 81(2), 1180-1185. http://dx.doi.org/10.1002/jsfa.927

United States Departament of Agriculture - USDA. (2013). National Nutrient Database for Standard Reference. (Release 18.2013). Washington: USDA. Retrieved from http://www.nal.usda.gov/ fnic/foodcomp

Universidade Estadual de Campinas - UNICAMP. (2011). Tabela brasileira de composição de alimentos - TACO (4. ed.). Campinas: UNICAMP/NEPA.

Villavicencio, A. L. C. H., Mancini-Filho, J., Delincée, H., \& Greiner, R. (2000). Effect of irradiation on anti-nutrients (total phenolics, tannins and phytate) in Brazilian beans. Radiation Physics and Chemistry, 57(3-6), 289-293. http://dx.doi.org/10.1016/S0969806X(99)00393-X

Whittaker, P., Fox, M. R. S., \& Forbes, A. L. (1989). In vitro prediction of iron bioavailability for food fortification. Nutrition Report International, 39(6), 1205-1215.

Xu, B. J., Yuan, S. H., \& Chang, S. K. C. (2009). Comparative analyses of phenolic composition, antioxidant capacity, and color of cool season legumes and other selected food legumes. Journal of Food Science, 72(2), S167-S177. PMid:17995859. http://dx.doi.org/10.1111/j.17503841.2006.00261.x 